\title{
Comparison Between Indonesia and the United States in Enforcement of Narcotics Illicit Trafficking
}

\author{
Jhoni Fernando Sinaga ${ }^{1,{ }^{*}}$ Ediwarman ${ }^{2, *}$ Mahmud Mulyadi ${ }^{3 *}$ \\ ${ }^{1}$ Legal Studies Program Universitas Sumatera Utara \\ ${ }^{2}$ Legal Studies Program Universitas Sumatera Utara \\ ${ }^{3}$ Legal Studies Program Universitas Sumatera Utara \\ Email: jhonnandosinaga@gmail.com ${ }^{1}$,profediwarman25@gmail.com², mahmud_mulyadi@usu.ac.id ${ }^{3}$
}

\begin{abstract}
The crime of illicit narcotics trafficking is a transnational crime and is included in an extraordinary crime, therefore its handling requires an extraordinary criminal policy. This research method is normative juridical with literature study and using qualitative analysis. The legal approach to illicit narcotics trafficking differs between Indonesia and the United States. Indonesia prioritizes penal efforts by taking action against perpetrators, while the United States prioritizes non-penal efforts by making efforts to prevent the occurrence of illicit narcotics trafficking, including closing access to trade routes from outside their country. The advantages of law enforcement on narcotics trade which are carried out with a penal law approach are able to eradicate illicit narcotics trafficking by arresting perpetrators and destroying illegal narcotics, while the weakness is that illegal narcotics still occur, especially those from other countries. Non-penal legal efforts that prioritize prevention are able to reduce the occurrence of illicit narcotics trafficking, but the weakness of prevention is that it requires cooperation between many countries and requires greater costs.
\end{abstract}

Keywords: crime, criminal policy, narcotis

\section{INTRODUCTION}

Narcotics crime is a crime that is not only national in nature but can be categorized as a transnational crime and is carried out using high modus operandi, advanced technology and is supported by an extensive network of organizations and has caused many victims, especially among the younger generation. As a form of extraordinary crime, its handling also requires an extraordinary form of punishment [1].

Based on Indonesia's positive law, the regulation of narcotics is regulated in Law Number 35 of 2009 concerning Narcotics. There are very strict sanctions against perpetrators of illicit narcotics trafficking, namely the death penalty. These provisions are regulated in Article 114, Article 115, Article 118, Article 119 which are adjusted to the category or severity of the crime committed.

Narcotics crimes have entered all aspects of life, therefore the death penalty is still needed and must be consistently applied in our country. However, even though the death penalty has been imposed, law enforcement on the decision seems to be stretched so that the convicts are still alive and carrying out their crimes even though they are in the Correctional Institution [2].
In 2019, drug abuse in Indonesia is increasing, especially in North Sumatra Province at an alarming rate. Drugs are a serious problem in North Sumatra. One group of users are teenagers whose number reaches more than 130,000. Last year, of the 3.6 million drug users in Indonesia, said Heru, $57 \%$ of them belonged to the category of trial and error. Then $20 \%$ is reactional or routine use at least twice a week. The rest, are addicts [3].

Drug eradication also requires an active role from the community which is carried out together. The basic problem of drugs is supply and demand. For this reason, preventive efforts must be made to create resistance (resistance) to the community to refuse and even combat the dangers of narcotics [4]. 
Based on data compiled from the National Narcotics Agency, the narcotics problem has made all countries in the world worried and restless. The United Nations Office on Drugs and Crime (UNODC) as a world body dealing with narcotics problems noted that at least 271 million people worldwide or $5.5 \%$ of the global population of the world's population with an age range of 15 to 64 years have consumed drugs, at least the person had consumed narcotics in 2017 (source: UNODC, World Drugs Report 2019). Meanwhile, the National Narcotics Agency (BNN) noted that the narcotics problem in Indonesia is still in a condition that requires continuous high attention and vigilance from all elements of the Indonesian nation [5].

Efforts to overcome the problem of addicts are in accordance with what has been regulated in the Narcotics Law in Chapter IX articles 53 and 54 which are still minimal in treatment and rehabilitation. The issuance of Government Regulation Number 25 of 2011 (PP Number 25 of 2011) concerning Mandatory Reporting for Narcotics Abusers, is a form of the state's commitment to accommodate the rights of addicts in obtaining therapy and rehabilitation services. Report (IPWL) which has been appointed by the government, because under the legal umbrella of Article 54 of the Narcotics Law and Government Regulation No. 25 of 2011 and Minister of Health Regulations No. 1305 and 2171 of 2011, abusers will not be thrown into prison if proven to only consume narcotics, but instead will get rehabilitation services [6].

Narcotics law enforcement, in practice it is still found that many users are subject to imprisonment or imprisonment, while the rehabilitation process is not carried out. In fact, in the Narcotics Law, there are provisions for sanctions that adhere to a double track system, namely in the form of criminal sanctions and action sanctions. Rehabilitation is one form of action sanctions. However, based on empirical facts in the field, it shows that judges tend to impose imprisonment on addicts [7]. As a result, narcotics addicts languish in Correctional Institutions (Lapas) without being given the opportunity to be rehabilitated, so that the implementation of rehabilitation has not run optimally. This has an impact on the full (over capacity) condition of the Correctional Institutions in Indonesia.

This condition results in the emergence of other problems such as the burden of correctional institutions hereinafter abbreviated as Lapas to be over capacity, prisons have become a safe place for drug abuse and the emergence of other criminal acts caused by drug abuse in prisons, besides that drug trafficking is also rampant in prisons and even some drug production was found in prisons. Basically, drug addicts have addictive properties with a high relapse rate, so they cannot recover by themselves. They need help to be healed [7].

Based on this, the implementation of imprisonment for narcotics addicts or users must be reviewed, and the implementation of rehabilitation is one alternative in reducing drug addiction. When compared to the United States, as a large country that is also experiencing the level of narcotics illicit trafficking on a large scale, it is slowly starting to succeed in suppressing and enforcing the law for narcotics traffickers. Therefore, the authors are interested in conducting a comparative study between Indonesia and the United States in law enforcement of narcotics illicit trafficking. Comparison of the legal system is also a legal study that is currently being developed as has been developed by Peter De Cruz [8]. Therefore, by comparing Indonesia with America in law enforcement against illicit narcotics trafficking, it will be an input in the formation of criminal policies in Indonesia.

\section{RESEARCH METHODS}

The method used in this research is normative juridical research [9]. The data sources used are secondary data in the form of primary legal materials, secondary legal materials and tertiary legal materials [10], such as laws and regulations relating to this research, namely laws and regulations relating to narcotics crimes, namely Law Number 35 of 2009 concerning Narcotics [9]. The data collection method used in this research is library research. All data in this study were analyzed qualitatively [11]. This qualitative analysis will be presented in the form of a systematic description by explaining the relationship between various types of data. Furthermore, all data is selected and processed, then analyzed descriptively so that in addition to describing and expressing, it is hoped that it will provide solutions to the problems in this study.

\section{RESULTS AND DISCUSSION}

\subsection{The Role of the Government of Indonesia in Enforcement of Narcotics Illicit Trafficking}

Narcotics abuse is an act that is contrary to the laws and regulations. Currently, narcotics abuse has covered all levels of society, rich, poor, old, young, and even children. Narcotics abuse from year to year has increased which ultimately harms the nation's successor cadres. Therefore, efforts to prevent and control narcotics and efforts to eradicate illicit trafficking are needed considering the progress of the development of communication, information and transportation in the current era of globalization [12].

The government has made efforts to prevent and eradicate the illicit trafficking of narcotics, but their abuse continues to increase. Basically narcotics are substances or drugs that are very useful and necessary for the treatment of certain diseases, but if abuse occurs such as being used not in accordance with treatment standards, it can have very detrimental consequences for the community.

In terms of actions, narcotics crimes can be classified as crimes involving the sale and purchase of 
narcotics, crimes involving narcotics possession, crimes involving the use of minors [13]. The narcotics business is indeed very promising, especially if the narcotics marketed can reach all over the world, the profits will be doubled.

The modus operandi of drug trafficking is increasingly sophisticated by utilizing modern technology. In the past, drug transactions were carried out by meeting directly between the seller and the buyer, there was money and goods. Now drug trafficking can be done by telephone and courier. So that the cases that are revealed are often only small-class couriers/distributors, while the big-name dealers or dealers are often unknown.

The entry of drugs into Indonesia cannot be separated from the international network of drug trafficking, because almost 70 percent of drugs circulating in the country are consignments from abroad. The drug trafficking business when viewed in terms of income can be said that the profits are very promising, of course the risks that will be experienced are also very large for dealers, as well as producers [14].

Drug trafficking and abuse in society must be prevented and addressed. This prevention effort must really be carried out in accordance with the issuance of the Narcotics Law so that the drug problem does not continue to grow in society and become a bad epidemic for the development of the country. This legal issue concerns the role of law enforcement officers, especially the police, whose existence is very important in the midst of society as a balancing servant of the state and protector of life in society. Lawrence M. Friedman's opinion states that, "All legal products, both in the form of laws and regulations, will definitely have an impact on the performance of law enforcement officers" [13].

As for the efforts that can be made by the Government which has the responsibility to make Indonesia free from Drug Circulation, namely by penal policies and can be pursued through several ways, including penal policies and non-penal policies.

\subsubsection{Penalty Policy}

Efforts to overcome crime through the "penal" route are more focused on the "repressive" nature (suppression/eradication/suppression) after the crime has occurred. While the "non-penal" path focuses more on the "preventive" nature (prevention/deterrence/control) before the crime occurs. It is said to be a rough difference, because repressive measures are essentially laws can be seen as preventive measures in a broad sense [14]. Within the framework of the Penal, there are 3 (three) simple ways to tackle illicit drug trafficking, namely: Prevention/preventive by the Government, ie prevention is far more beneficial than cure which can be done with general prevention and preventive action from law enforcement agencies.
Drugs are an international epidemic that will spread to every country, whether the country is developed or developing. All have been targeted by drug syndicates, facing this reality, the Central Government and Regional Governments have attempted to issue several regulations in the form of Presidential Instruction No. 6 of 1971, Law No. 9 of 1976, Decree of the Minister of Health No. 65/Menkes.SK/ IV/1997, Decree of the Minister of Health Number: 28/Menkes/Per/I/1978 Narcotics Deviations, Law Number 22 of 1997 concerning Narcotics Crime, Law Number 35 of 2009 concerning Narcotics.

Improvement of law enforcement agencies, based on the provisions of Law Number 35 of 2009 it is clear that prosecution of narcotics crimes is carried out by law enforcement institutions that have the authority to carry out investigations and investigations such as Police Investigators, Investigators at the National Narcotics Agency (BNN), Civil Servants Investigators in Ministries/Government agencies such as Customs, Taxes and so on.

Action against drug traffickers will be determined or determined based on evidence. Perpetrators of drug trafficking crimes are subject to basic penalties such as the death penalty, imprisonment, confinement, fines or additional penalties. Therefore, in terms of taking action against illicit drug trafficking, it is carried out jointly between law enforcement institutions so that eradication of illicit drug trafficking can be carried out.

\subsubsection{Non Penalty Policy}

Non-penal policies on efforts to overcome and eradicate narcotics abuse are very important to be carried out as early as possible, because prevention is certainly better than cure, in the sense that prevention efforts are better, cheaper, and more cost-effective than other efforts. In addition, it is also a strategic effort to eliminate risk. Prevention is an effort to help individuals avoid starting or trying to abuse narcotics and psychotropic substances, by living a healthy way and lifestyle, as well as changing living conditions that make individuals susceptible to drug abuse.

The Indonesian government and local governments can take non-penal actions or efforts in eradicating drug trafficking by doing several things including: building cooperation between law enforcement agencies, conducting gradual and continuous outreach to all elements of society, educational institutions, offices, and universities. Collaborating with companies in their respective areas to carry out routine checks on drug abuse for employees/workers in the company, establishing cooperation with Regional Hospitals, private hospitals in providing medical rehabilitation service facilities for drug addicts, carry out routine campaigns through print, electronic and internet media against illicit drug trafficking in their respective areas, carry out regular and comprehensive control and supervision of night entertainment venues so that drug 
trafficking can be prevented, build Regional Rehabilitation facilities with APBD funds both for rehabilitation medical or social rehabilitation for drug addicts, forming the RENSTRA of their respective local governments as a form of commitment to drug eradication, forming and conducting training for drug eradication cadres at the District/City sub-district level in collaboration with the Police and/or BNN institutions.

Trafficking of drugs by sea is also often done. The territory of Indonesia, which is $80 \%$ of the ocean, is the gateway for the entry of drugs into Indonesia. Not all areas can be monitored optimally by officers from the National Police, the Navy and other relevant departments. Not to mention the lack of control that is very vulnerable to being used by unscrupulous officers to pass drugs into Indonesia, hoping to get a reward or bribe.

Circulation of drugs through the air is also vulnerable to become access for drugs to enter Indonesia. Although several airports in Indonesia are equipped with sophisticated drug detection devices, there are still many airports that do not have them. Moreover, the longer the mode and efforts of drug smuggling into Indonesia are growing, starting from couriers of children and women to unreasonable ways such as swallowing drugs by wrapping them in a special kind of wrapper to avoid detection of drugs by officers.

In carrying out countermeasures against drug abuse and illicit trafficking, the National Police can cooperate with ministerial and non-ministerial government agencies, such as the Director General of Customs and Immigration, the Ministry of Religion, the Department of Tourism, Arts and Culture, the National Police Agency, the Attorney General's Office, the Judiciary, the National Narcotics Agency (BNN)., and others. In Law Number 35 of 2009 it is also explained that the Indonesian National Police Investigators and BNN investigators are authorized to conduct investigations into the abuse and illicit trafficking of Narcotics and Narcotics Precursors. And in practice, investigators from the Indonesian National Police and BNN investigators can cooperate and coordinate in conducting investigations on abuse and illicit trafficking of Narcotics and Narcotics Precursors.

\subsection{Drug trafficking law enforcement in the United States}

Based on information data, it was found that Mexico is the main supplier of drug trafficking in the United States. Mexican drug cartels dominate the supply, trade, and distribution of United States drugs. The dominance of Mexican drug cartels aims to control the southwest lane of drug smuggling in the United States. In addition, to develop production, transportation and distribution capacity. The dominance of Mexican drug cartels in the United States is supported by Mexico's geographical location which borders directly with the United States. The geographical location of the Mexican-United States border is very strategic, making Mexico an ideal place for transit for drug dealers. Most of the drugs circulating and consumed by the people of the United States come from Mexico. In addition, the development of drug cartels and the increase in drug trafficking from Mexico are also caused by the demand for drugs from the people of the United States [14].

In 2007, approximately 24,000 Americans had died from drug abuse. According to the United States Congressional Research Service, from 2006 to 2011, there were 50,000 homicides related to drug trafficking. Drug trafficking is not only a threat to the United States, but also a threat to Mexico. Between 2001 and 2007, there were 11,080 victims of homicides related to drug abuse and trafficking. Meanwhile, in 2006 to 2012, violence caused by drugs has claimed 50,000-70,000 lives in Mexico. In addition, in 2006 to 2011, the death toll from drug violence was estimated at 47,515 at the Mexico-United States border [14].

The presence of Mexican cartels in the United States has made the circulation of narcotics in the United States increase. The Mexican cartels in the United States are not only concentrated in states that are the gateway for narcotics to enter the United States including Texas, California, New Mexico, Arizona, but spread in several cities throughout the United States such as Detroit, San Diego, Phoenix, El Paso, Dallas, Los Angeles, Miami, San Antonio, Chicago, Houston, and the city of Denver. [15]. The coastal area is the area of choice for Mexican cartels as their territory in running the narcotics business. The coastal area is chosen because it makes it easier for Mexican cartels located in the United States to distribute narcotics supplies sent from Mexico through United States waters [16].

The national policy strategies of one country and another are quite different in terms of the resources they deploy. Some countries (especially the United States) spend millions of dollars annually to implement their national policy strategies, while others spend very little. These expenditures can come from the cost of education, law enforcement, and health costs, which have an impact on the achievement of strategic goals. The results of the national evaluation prove that the eradication of narcotics has not been achieved significantly. It recommends that policy makers must understand the total costs incurred to finance proactive Narcotics policies (such as financing harm reduction programs and treatment for Narcotics addicts, law enforcement processes, prevention campaign activities), as well as the savings that can be made from some "reactive" activities (including the cure of HIV or other diseases that are transmitted through blood due to the use of injection needles, narcotics use, narcotics crime, and the resulting economic loss).

The eradication of the illegal Narcotics market will never be fully carried out by law enforcement (the duration of operations that take a long time and cost a lot of money in eradicating one group will only lead to 
the emergence of the replacement of that group with another group). This situation encourages strategies and interventions focused on reducing the activities of criminal organizations and individuals whose actions are most detrimental to society, such as interference with legitimate economic activities, corruption by officials and institutions, violence and intimidation of law-abiding citizens. Actions against organized crime groups must be based on a sound understanding and focus on the impact of operations carried out on society. This is a stimulator in making priority decisions, focusing on the harmful aspects of their actions as opposed to confiscation and arrest, and encouraging the Narcotics trade market to be moved from public places or by relying on non-violent friendship networks. [16].

In the United States, law enforcement efforts against narcotics illicit trafficking are focused on tackling organized crime, overcoming problems related to the retail market, reducing the availability of narcotics for young people, reducing the rate of minor crimes committed by drug addicts, supporting health and social programs [17].

Narcotics retail market activities can take place in several ways, can occur in public or private places; concentrated or dispersed and controlled by a small number of dominant groups or large social networks. The harm to society caused in different types of retail markets can have different impacts, including visibility, violence, or intimidation.

Incidents during operations on trafficking groups that have an impact on increasing violence through the struggle for vacant "positions", or the emergence of more terrible organizations. Another example is the activities of narcotics trafficking raids that are concentrated in private building areas, causing the effect of moving the market concentration center to a public place close to community settlements, schools, public services, or to dangerous areas. Narcotics retail market is generally more dangerous the conditions differ from place to place, when it occurs in public, concentrated and involves groups and individuals who commonly use violence, intimidation, and corruption to protect their business. The basis of a good and correct understanding is a law enforcement strategy in the retail market. It aims to analyze the methods and forms of trading markets that are often used to deceive law enforcement officers, as well as minimize the dangers that can be caused [17].

The case of handling narcotics in the city of High Point, Carolina is one example of an illustration where the police use the Boston model. The police recorded the youth drug dealers who were in the local Narcotics market for a long time. The police contacted their parents and other people who could influence the young people, then approached drug dealers with the information they found from these people. The police made these dealers aware that there was a high risk of imprisonment if they continued their activities. This initiative has had an impact with arrests after two years and violent and property crime rates falling by $25 \%$ after two years and currently the local Narcotics market is no longer operating in the city [18].

Harvard economist Jeffrey Miron states that, the United States had spent 15.2 billion dollars to finance narcotics prisoners in 2006. American studies suggest that, in the early 1990s, it was estimated that the annual cost of a detention room was more expensive than the cost of dormitories, room fees, and education, at Harvard University. The hefty costs of detention are not unique to the United States. On the northern border, Canada spent nearly three billion dollars in prison costs in 2005-2006. Such funds allocated to imprison narcotics criminals divert resources from vital socioeconomic and health-related programs such as housing, education and addiction recovery, which are crucial in dealing with Narcotics problems and maintaining social conditions to prevent people from using Narcotics [18].

In the United States, it has been found that the imposition of mandatory minimum sanctions and pretrial imprisonment. The reputation and efficiency of the country's judicial system can be damaged by the increased imprisonment of nonviolent criminals. The criminal law that results in a perpetrator of a light narcotics crime being in prison longer than the perpetrator of a bank robbery, kidnapping and other perpetrators of violence (such as rapists or murderers) have hindered the principles of proportionality and justice in the legal system. The criminal justice system filled with minor narcotics crimes can also weaken the ability of court administrations to run justice efficiently and shift focus away from other, higher-level offences.

The implementation of the United States' international agreements with several countries for law enforcement and prevention of illicit narcotics trafficking is an unavoidable impact of the development of world globalization. This means that the power of international law is still needed in overcoming national legal issues [19]. The creation of a universal legal order motivates many legal activities, safeguards human rights and universal legal standards [19]. Therefore, law enforcement for perpetrators of criminal acts is also influenced by international law in the form of international cooperation in several countries, including Indonesia and the United States in law enforcement of the eradication of illicit narcotics trafficking.

\section{CONCLUSION}

Law enforcement against illicit narcotics trafficking carried out in Indonesia is based on penal and non-penal efforts, with more emphasis on penal law enforcement efforts by enforcing Law Number 35 of 2009 concerning Narcotics. However, law enforcement through non-penal efforts in Indonesia has not been implemented optimally. So that narcotics traffickers continue to occur and are increasing. Penal and non- 
penal efforts should be carried out in a balanced and proportional manner.

In the United States, law enforcement for the illicit trafficking of narcotics is carried out by prioritizing non-penalty efforts, namely by closing the border access where narcotics enter the United States, and the United States Government carries out a policy of exterminating narcotics trafficking retailers that occur in several states of the United States that are directly adjacent to the United States. with narcotics producing countries, such as Latin America, Ecuador, Mexico and Colombia. In addition, the United States seeks to be able to stop or suppress the distribution of drugs from African countries such as Nigeria to the United States by conducting security cooperation with Nigeria through joint coordination to be able to tackle trafficking. drugs in Nigeria. This joint coordination was then realized through the Cooperation Security Initiative program in which the United States provided financial assistance, technical assistance and security assistance which was realized together with Nigeria. The Cooperation Security Initiative program is a form of non-military effort by the United States in dealing with drug trafficking cases, considering that in several countries such as Mexico and Colombia, the United States also plays a role in handling drug problems in these two countries but through military efforts.

The legal approach to illicit narcotics trafficking differs between Indonesia and the United States. Indonesia prioritizes penal efforts by taking action against perpetrators, while the United States prioritizes nonpenal efforts by making efforts to prevent the occurrence of illicit narcotics trafficking, including closing access to trade routes from outside their country. The advantages of law enforcement on narcotics trade which are carried out with a penal law approach are able to eradicate illicit narcotics trafficking by arresting perpetrators and destroying illegal narcotics, while the weakness is that illegal narcotics still occur, especially those from other countries. Non-penal legal efforts that prioritize prevention are able to reduce the occurrence of illicit narcotics trafficking, but the weakness of prevention is that it requires cooperation between many countries and requires greater costs.

\section{ACKNOWLEDGMENTS}

The researcher would like to thank the University of North Sumatra (USU), especially the Doctoral Program of the Faculty of Law, USU which has provided facilitation in the publication of this scientific work, hopefully this work can be useful and become a reference for the development of future legal research.

\section{REFERENCES}

[1]. Ferawati. Kajian Hukum Dan Ham Terhadap Penjatuhan Pidana Mati Bagi Terpidana
Narkotika. J Ilmu Huk. 2014;4(3):138.

[2]. S. Kolopita. Penegakan Hukum Atas Pidana Mati Terhadap Pelaku Tindak Pidana Narkotika. Lex Crim 24 [Internet]. 2013 [cited 2021 Aug 7]; Available from: https://ejournal.unsrat.ac.id/index.php/lexcrimen /article/view/3089

[3]. Benny Pasaribu. BNN: 130.000 Lebih Remaja di Sumut Gunakan Narkoba [Internet]. Medanbisnisdaily. 2019. Available from: https://mdn.biz.id/o/83986/

[4]. Tribun Medan. Gawat, Sumut Peringkat Ke-2 Pengguna Narkoba Terbesar di Indonesia, Ini Tindakan dari BNN Sumut Artikel ini telah tayang di Tribun-Medan.com dengan judul Gawat, Sumut Peringkat Ke-2 Pengguna Narkoba Terbesar di Indonesia, Ini Tindakan dari BNN Sumut, http [Internet]. TribunMedan.com. 2019. Available from: https://medan.tribunnews.com/2019/01/31/gawa t-sumut-peringkat-ke-2-pengguna-narkobatersebesar-di-indonesia-ini-tindakan-dari-bnnsumut?page $=3$

[5]. Nasional BN. Jadikan Narkoba Musuh Kita Bersama. Press Release Akhir Tahun. Jakarta. 2019.

[6]. Arifin T. Implementasi Rehabilitasi Pecandu Narkotika Dalam Undang-Undang Republik Indonesia Nomor. 35 Tahun 2009 Tentang Narkotika Sebagai Upaya Non Penal Badan Narkotika Nasional. Universitas Brawijaya; 2013.

[7]. Krisnawati D, Hukum NU-[DUMMY] JM, 2015 undefined. Pelaksanaan Rehabilitasi bagi Pecandu Narkotika Pasca Berlakunya Peraturan Bersama 7 (Tujuh) Lembaga Negara Republik Indonesia. scholar.archive.org [Internet]. 2015 [cited 2021 Jul 30];27(2):226-40. Available from:

https://scholar.archive.org/work/hpepqt5zijg6vp e53kwsdvvenu/access/wayback/https://jurnal.ug m.ac.id/jmh/article/viewFile/15894/10503

[8]. Hatzimihail N. Comparative Law in a Changing World. 2000 [cited 2021 Jul 30]; Available from: https://heinonline.org/hol-cgibin/get_pdf.cgi?handle=hein.journals/lejint13\&s ection $=38$

[9]. Ibrahim J. Teori dan metodologi penelitian hukum normatif. Malang: Bayumedia Publishing, 57; 2006. 295 p.

[10]. Peter Mahmud Marzuki. Penelitian Hukum. Jakarta: Kencana; 2006. 141 p.

[11]. Muslan Abdurrahman. Sosiologi dan Metode Penelitian Hukum. Malang: UMM Press; 2009. $121 \mathrm{p}$.

[12]. Lydia Harlina Marton. Membantu Pencandu Narkotika dan Keluarga. Jakarta: Balai Pustaka; 2006. 1 p.

[13]. Taufik Makarao. Tindak pidana Narkotika. 
Jakarta: Ghalia Indonesia; 2003. 26 p.

[14]. Novianto MR. Upaya Penanggulangan Yang

Dilakukan Oleh Kepolisian Dalam Memberantas Tindak Pidana Peredaran Narkoba Dikalangan Narapidana (Studi di Polisi Resort Malang Kota). J Hukum, Univ Brawijaya. 1(2).

[15]. Sudarto. Kapita Selekta Hukum Pidana. Bandung: Alumni; 1981.118 p.

[16]. Naomi Putri L.M. Efektivitas Perjanjian Bilateral Amerika Serikat Dan Kolombia Mengenai Pemberantasan Peredaran Narkotika Ilegal Di Amerika Serikat (2003-2008). JOM FISIP. 5(1):4.

[17]. Mega Wahyu Pratiwi. Implementasi Kerjasama Merida Initiative Antara Amerika Serikat Dan Meksiko Dalam Penanggulangan Peredaran Narkoba Ilegal (2008-2010). J Glob Policy. 6(1):53-4.

[18]. Caulkins JP, Reuter P. Towards a harmreduction approach to enforcement. Safer Communities. 2009;8(1):9-23.

[19]. European Monitoring Centre on Drugs and Drug Addiction (EMCDDA). 2004 Annual report: the state of the drugs problem in the European Union and Norway (Lisbon: European Monitoring Centre on Drugs and Drug Addiction) [Internet]. 2004. Available from: https://www.emcdda.europa.eu/system/files/pub lications/923/ar2004-en1_69524.pdf 